\title{
THE ROLE OF PENTAHELIX ACTORS FOR SAWAHLUNTO CITY TO BE DEEMED A UNESCO WORLD HERITAGE
}

\author{
Reza Permadi, Fahriza Junizar, Nurul Aldha Mauliddina Siregar, Ute Lies Siti \\ Khadijah \\ School of Graduate \\ University of Padjadjaran, Bandung \\ nurul.aldha@gmail.com
}

\begin{abstract}
The coal mine closures have turned Sawahlunto into an idle city. By integrating the postmining sites landscape and the Dutch colonial architecture heritage, Sawahlunto becomes a city of a kind. Therefore, the local government and the legislature (DPRD) as well as other stakeholders created a vision for Sawahlunto as a "A Cultural Tourism Mining City" in 2020, set in Local Government Regulation (PERDA) No 2 of 2001. The year 2020 was set as a target to motivate the local government and stakeholders to achieve the vision. As a matter of fact, Sawahlunto has been included as a World Heritage site by UNESCO as of 2019. This research aims to understand the role of stakeholders in developing and rebranding Sawahlunto, by using the Pentahelix model. This research uses a qualitative method along with the case study approach as well as utilizing interviews, observations and archival study as the types of research methodology. Finally, the result of this research shows that the stakeholders carry out their roles well and fully support the vision of Sawahlunto city..
\end{abstract}

Keywords: Pentahelix model; Unesco Heritage; Sawahlunto; Pentahelix actors

\section{INTRODUCTION}

The implementation of regional autonomy in Indonesia provides the opportunities to significantly optimize the development and management of the cities and regions based on their potential. The delegation of authority from central government to regional government in order to regulate the development of its region, creates opportunities to optimize the local culture based on the quality and uniqueness of each region. This momentum was seized well by the local government of Sawahlunto to create a breakthrough for the city that had experienced a decline in economic growth due to the decrease of coal production, which had already become a backbone of the Local Own Source-Revenue (PAD) ever since.

The Ombilin Coal Mining of Sawahlunto has records on its faltering journey from the Netherlands East Indies' government up to now. In the beginning, Sawahlunto was developed by the colonials to be accessible as the coal mine region in 1891. The invention of the steam engine led to the drastically increased demand 
in the coal industry which also contributed to the peak of coal production in Sawahlunto. Approximately 1920 to 1921, the coal reserves in Sawahlunto was estimated to be 250 millions tons.

The high coal reserves urged the Netherlands East Indies to recruit the workforce outside Sawahlunto in order to exploit the exceedingly rich Ombilin coal deposits, which triggered the locals' attention. The urbanization of the population took place in Sawahlunto where it used to be known as a rather isolated city as it is geographically located between valleys surrounded by hills. It has turned into a bustling city.

The Netherlands East Indies' government hence developed Sawahlunto by integrating urban planning and modern technology in order to equip the mine officials with proper facilities such as housing, economic zone, service and commercial areas. Following the increase of coal demand, the city development attracted more workers in different sectors of service and entertainment. The fast growth and more populations coming made Sawahlunto an administrative city elected by the Netherlands East Indies's governmentn in 1918. Sawahlunto developed into a mining city with the best mining technology at that time.

The glory days of coal production, unfortunately, did not last long. It was caused by several factors affected by the decrease of coal demand that had been replaced by other environmental-friendly energy sources, global coal price drop, as well as the proliferation of illegal mining (PETI) in 1996 which caused the coal management in Sawahlunto came to a halt.

Ombilin Coal Mining Unit (UPO), the BUMN subsidiary, PT Bukit Asam which was appointed by the Indonesian government to manage the coal mining sites in Sawahlunto, recorded that in 1998 the coal production achieved $99 \%$ of targeted goal (Zubir \& Zulqayyim, 2014). The decrease of coal demand took place at the end of the New Order era approximately in the early 1999. As of 2002, the open mining activities of PT. BA-UPO in the post-mining area around Kandi and Tanah Hitam were officially not operated. The coal mine closure and the drastic decline of coal production automatically shifted the condition of Sawahlunto. The population gradually left the city and turned it into a Ghost Town.

After the coal's heyday, Sawahlunto was not developed in terms of infrastructure, transportation, industry and employment (Suprayoga, 2008). The sole economic driver of Sawahlunto was illegal minings by the locals which also decreased drastically that made most of the populations moved to other cities.

Facing the more difficult situations, the local government initiated a talk between legislators and the community to find a solution on how to revive the city. The evaluation resulted in formulating a new vision to develop the city in the tourism sector as an alternative to drive the economic growth. There are three reasons why tourism becomes an alternative for the region to develop its economy. Firstly, the tourism sector is one of the biggest contributors to the foreign exchange annually. It means that the tourism sector could provide profitability to the government's balance sheet. Secondly, 'quick yielding' characteristics of tourism could immediately generate foreign exchange in contrast to conventional export. Lastly, the high labor absorption also became a hope to alleviate poverty (Bank Indonesia, 2018).

Several Local Government Regulations (PERDA) were issued to stimulate long term commitment towards the intention of tourism development there. The 
vision of the tourism city was initially mentioned in the Local Government Regulations (PERDA) no. 2 of 2001 on the vision to become a "Cultural Tourism Mining City 2020" which is gradually being updated. The mine sites management is also being revitalized in terms of layout and uses. The Dutch-era office buildings were modified into museums that have tourism value which gradually increased the number of tourists.

Table 1. The Number of Tourists Visited Sawahlunto in 2013-2017

\begin{tabular}{cc}
\hline Year & $\begin{array}{c}\text { Number Of Tourists } \\
\text { (Person) }\end{array}$ \\
\hline 2013 & 750.385 \\
\hline 2014 & 760.243 \\
\hline 2015 & 974.004 \\
\hline 2016 & 858.355 \\
\hline 2017 & 870.999 \\
\hline
\end{tabular}

Source: The Department of Youth, Sport and Tourism of Sawahlunto City (edited), 2020

The increasing number of visitors generated a multiplier effect towards the emerging tourism support business. The 2005's poverty rate of $17.18 \%$ in Sawahlunto was reduced to only $2.41 \%$ in 2009 thanks to tourism development (Asoka, Samry, Zubir, \& Zulqayyim, 2003).

The vision to develop a coal mining tourism in 2020 was attained not solely of the local commitment but also leveled up to be the candidate of the UNESCO's cultural heritage in 2015. Sawahlunto then successfully added to their collection of world acknowledgment as the fifth of Indonesia's cultural heritage after six years of gap from the previous acknowledgment of the Subak System in Bali (2012).

Among the ten criteria listed by UNESCO, two represented the strong value owned by Ombilin Coal Mining in Sawahlunto. The first criteria is number 2 "to exhibit an important interchange of human values, over a span of time or within a cultural area of the world, on developments in architecture or technology, monumental arts, town-planning or landscape design". This was shown by the historical heritage of exchange and fusion between local knowledge and practices and European technology in managing the mines especially between 19th to 20th century in South East Asia.

The other criteria is number 4, "to be an outstanding example of a type of building, architectural or technological ensemble or landscape which illustrates (a) significant stage(s) in human history". The technological ensemble includes deep bore vertical tunneling of mine shafts, mechanical ore washing and sorting, steam locomotion and rack railway, inclined and reverse-arc rail bridge construction, rock-blast railroad tunnels, deep-dredge harbours, and coal storage in climatecontrolled silos. 
The shift from mining as the main sector of economy to tourism and even the world acknowledgment was driven by the involvement and support of the authorities and multi stakeholders in the city. UU no. 9 of 2010 stated that tourism activities must be held with the principle to guarantee the cohesiveness among sectors, regions, central and locals that have become a systemic unity in regional economy and the cohesiveness among authorities. This means that tourism development must be done in collaboration, not by a single actor.

Pentahelix is a term or reference of the collaboration concept among stakeholders. Based on Lindmark, Sturesson, and Nilsson-Roos (2009), Pentahelix is a form of collaboration or synergistic activities among stakeholders that consisted of Academic, Business, Community, Government and Media or abbreviated as ABCGM which is considered to accelerate the potential development of an innovation. While according to Soemaryani (2016), Pentahelix model is a reference in developing a synergy between relevant agencies in supporting as optimal as possible in terms of achieving the goal. This research aims to understand the role of stakeholders using Pentahelix model in developing or rebranding Sawahlunto in achieving the vision of a Cultural Tourism Mining City 2020 which then included in the UNESCO World Heritage.

\section{METHODOLOGY}

This research uses a qualitative method. Sugiyono (2010) stated that in a qualitative approach, the researcher acts as the key instrument. The qualitative research was selected considering the phenomenon that wants to be explored could not be quantified due to the nature in description such as the meaning of varied concepts, characteristics of product or service, pictures or styles, cultural manner, physical model of artifacts and others (Komariah \& Satori, 2011).

This research uses case study as the approach. Yin (2015) stated that case study research focuses on the questions of Why and How a phenomenon happens, especially when the researcher has little chance to control the event and if the research focus takes place in the contemporary phenomenon (present) in the real life context. In applying qualitative methods, researchers must consider their understanding, both in the planning process and during the analysis process, to minimize self-bias (Elo et al., 2014).

To avoid biased assumptions from researchers, data collection was carried out comprehensively. Primary data collection in this study was carried out by observation. Creswell (2014) defines observation in qualitative research as recording activities carried out by researchers about the behavior and activities that occur in a study. Observation in this study was carried out by analyzing regulations, especially regional regulations, data related to the historical heritage of the city of sawahlunto, and direct observation in the city of Sawahlunto. In-depth interviews were also conducted in order to draw primary data from the speakers by submitting open-ended. Three parties that were successfully interviewed included academics from ITB as cooperation partners in the development of Sawahlunto, staff of the Sawahlunto city cultural heritage and museum, and the head of the Indonesian tourism guide association, Sawahlunto City. Interview questions include the perspectives of each stakeholder regarding their role in developing Sawahlunto City. Meanwhile, secondary data were collected using studies of the literature or supporting documents. The interview was conducted in June-July 2020. The 
collected data was managed by triangulation. Analysis of research data was carried out by means of data reduction, data exposure, and conclusions.

\section{RESULTS AND DISCUSSION}

The Sawahlunto's transition from the vision of mining town to the Cultural Tourism Mining City was based on the historical events, current condition and opportunities in the future. The implementation of regional autonomy revealed the collaboration channel for the government to innovate and develop its region. To actualize the vision, each stakeholder has to adopt the Pentahelix elements where each has role as follows:

Government

The entry to regional autonomy regulations based on UU no. 22 of 1999 about the local government became the first milestone of the Sawahlunto revolution as the tourism city (Presiden Republik Indonesia, 1999). From the local government side, the commitment to plan the new vision of Cultural Tourism Mining City as the new identity of Sawahlunto was regulated in the Local Government Regulation (PERDA) no. 2 of 2010 on the vision and mission of the city. This becomes the basic principle to shape the common perspective (Pemerintah Kota Sawahlunto, 2010). The regulation was commenced to be the strategic reference to coordinate each party to have the same vision and mission in viewing the issues in Sawahlunto. The reshuffle in leadership did not remodel the development policy in Sawahlunto associated with the rebranding as the tourism city.

The eagerness to initiate the vision and mission of Sawahlunto as the Cultural Mining Tourism City was pursued well under the leadership of Mayor Amran Nur. His leadership resulted in a master plan of the city development which consisted of a strategic plan to expand the tourism in Sawahlunto. Some acknowledged Amran Nur as the key person in improving the aspiration to develop tourism in Sawahlunto (Syafrini \& Fernandes, 2017). The tourism strategic plan is still being maintained, improved and evaluated until now. The leadership of Mayor or Governor in local government carries out the synergistic coordination among stakeholders in order to achieve the vision of development.

Table 2. List of Local Government Regulations (PERDA) that Stipulates Strategy, Vision and Mission of the Tourism Development of Sawahlunto.

Regulations

Local Government Regulation (PERDA) of

Sawahlunto No. 2 of 2001 on the City's

Vision and Mission (the government gazette

of Sawahlunto 2001 No. 2 of 2001 series

D.2)

Local Government Regulation (PERDA)

No. 6 of 2003 on the Strategic Plan of

Sawahlunto Government in 2003-2008.

\section{Content}

The vision of Sawahlunto is to become a "Cultural Tourism

Mining City in 2020"

The long-term vision and mission of Sawahlunto up to year 2008 in the tourism sector.

The Drafting Team Formation of Sawahlunto's Master Plan as the Tourism City 2019-2025 


\begin{tabular}{ll} 
Master Plan as the Tourism City 2019-2025. & $\begin{array}{l}\text { comprises of seven teams based } \\
\text { on each assignment and function } \\
\text { to prepare the information for the } \\
\text { tourism development strategy. }\end{array}$ \\
\hline $\begin{array}{l}\text { Local Government Regulation (PERDA) of } \\
\text { Sawahlunto No. } 1 \text { of } 2019 \text { on the }\end{array}$ & $\begin{array}{l}\text { The vision of Sawahlunto is to } \\
\text { become a "Cultural Tourism } \\
\text { Sawahlunto's Master Plan as Tourism City. }\end{array}$ \\
$\begin{array}{l}\text { Mining City in 2020 and has } \\
\text { competitive value in 2023" }\end{array}$
\end{tabular}

Source: Various sources (edited), 2020

Setting the vision and mission of Sawahlunto in the form of Local Government Regulation (PERDA) signifies the active role of Sawahlunto's local government as a public administrator to establish the collective perspective of other actors so that the collaboration could be directed to the common responsibility towards the city's vision and mission. Rebranding the vision and mission in the form of regulation becomes the local government's method to actualize the development by growing partnership networking with the same perspective in the multi stakeholders' communication, or in other words not solely dependent on the bureaucracy instruction but also the common goal.

These vision and mission regulations create a consensus in establishing the stakeholders' commitment to develop the locals' welfare based on the involvement of private entities, academics, media and the local community itself independently to adjust with the vision and mission and no longer driven by the government in an authoritarian way. According to Ansell and Gash (2008), commitment to the process becomes one of the main supports of the Collaborative Governance. The factors that form a commitment are (1) mutual recognition of interdependence, (2) mutual appreciation, (3) openness among actors and (4) shared ownership of process. By setting the vision and mission into the local government regulation creates the mutual commitment as a guidance for stakeholder to understand the direction and purpose of partnership in the development of Sawahlunto.

Regulations are also established as the foundation to legitimate the law aspect which becomes a part of the post-mining tourism-based developer. The biggest challenge for the government is to organize the locals who have already resided in the area of mining heritage. Through the socialization and gradual organization to the locals, the cultural heritage buildings can be restored progressively. Anticipating the arrival of people coming to the city, the Center for Preservation of Cultural Heritage (BP3) at Batusangkar conducted a data collection and reweighting of objects that have historical value.

In 2006, there were 68 buildings appointed as the Cultural Heritage of Sawahlunto set in the Mayor's Decree (SK Walikota) No. 9 of 2006 on the Stipulation of Buildings, Complex, Sites and Features. The decree was then revised as the Mayor's Decree (SK Walikota) No. 109 of 2007 on the Stipulation of Historical Area, Buildings, Complex, Sites and Features as the cultural heritage (Pemerintah Kota Sawahlunto, 2007). Afterwards, the data result was endorsed on the Local Government Regulation (PERDA) No. 6 of 2007 on the Stipulation of Buildings, Complex, Sites and Features as the Cultural Heritage in 2007. Lastly, 
there were 6 sites added as the cultural heritage in 2014 (Pemerintah Kota Sawahlunto, 2007).

Apart from being a regulator, the other role of Sawahlunto's local government is also as a dynamist among stakeholders whether in the private sector, local communities or the government itself. Several central ministries were also involved in achieving the vision and mission of Sawahlunto. There were the Ministry of Tourism, Ministry of Public of Works and Housing, Ministry of Education and Culture and Ministry of State Owned Enterprise.

In addition, a bilateral cooperation was also initiated by the local government through a "Friendship City: Memorandum of Understanding (MoU) Between Melaka City Council Historic City and Municipal City of Sawahlunto, West Sumatra Province" in 2003 with the Malacca city in Malaysia that owns a background similarities with Sawahlunto. A number of the state's civil apparatus also participated in a comparative study to Malacca city. In addition to Malacca, the local government also partnered with the Dutch government (Asoka et al., 2003).

Academics

The tourism development in Sawahlunto is highly associated with the involvement of academics. Similar to the concept of academics in Pentahelix as the source of knowledge Muhyi, Chan, Sukoco, and Herawaty (2017), the academics in Sawahlunto also carry a role to deliver a concept, develop a theory to generate a long-term benefit. From the beginning of Sawahlunto's vision in 2020, the local government has been in collaboration with the Community Empowerment Board (LPM) of ITB to establish the strategic concept of tourism development in Sawahlunto. This collaboration resulted in the Local Government Regulation (PERDA) No. 6 of 2003 on the Strategic Plan of Sawahlunto in 2003-2008 (Pemerintah Kota Sawahlunto, 2003). The partnership between ITB and the local government of Sawahlunto was specifically based on ITB's track record as the educational institution that has been handling and analyzing regional development especially in urban planning.

Eventhough the partnership between LPM ITB and the local government of Sawahlunto initiated in 2003 but it is still proceeding both formally and informally in form of study visits, evaluation and recommendation the research result. Above signifies the role of academics as the actor involved in the development of Sawahlunto's vision and mission. Academics do not only act as the 'think tank' to review the decrees of the local government to result in a neutral, knowledge-based, away from other people's interests but also acts as the one who summarizes the track record of the development, which is an outcome in a research result. This can be understood and studied as the structured learning documents.

Furthermore, the development of vision and mission as the tourism city as well as the long history of Sawahlunto have become another attraction for the world of research in terms of various perspectives such as engineering science, social, culture, economy and tourism. The research partnership is another segment that has been developed by the Sawahlunto government in order to improve its city. The benefit of having the researcher in Sawahlunto does not only impact the the production of scientific publications to encourage innovations in the human resources (SDM) and natural resources (SDA) but also to drive the profit generation by bringing in the group of expat researchers or students to stay in a longer period of time. Therefore, the reinforcement of the academics's role in developing the 
Sawahlunto has become the strategic approach to invite more researchers to Sawahlunto.

Since the development of the city, there have been several universities from in and outside Indonesia that have established partnership with Sawahlunto. The projects are as follow: the revitalization of Goa Mbah Suro, the historical old city initiated by the local government with the Programma Uitzending Managers (PUM)-The Netherlands, ICOMOS-The Netherlands and St. Thomas University of Medan (Asoka et al., 2003) as well as the master plan of Danau Kandi Resort establishment with Bung Hatta University.

Business

Inevitably, revitalizing a city requires a lot of money. It is surely not sufficient to depend only on the state budget (APBD) especially in the middle of economic slowdown due to the uncertain fluctuations of coal price. The private sector in Sawahlunto also took part in attaining the vision and mission of 2020. The role of the private sector, mainly as an investor, does not only encourage the labor absorption but also acts as the vital support in creating the technical innovation of tourism development in Sawahlunto.

The collaboration in the form of Corporate Social Responsibility (CSR) has a significant role in generating stimulus to achieve the vision and mission of Sawahlunto. The CSR activities in Sawahlunto are implemented philanthropically and focused more on community empowerment.

The CSR funds in Sawahlunto have significantly become the alternative besides the government funds to support the people's transformation to achieve the vision and mission of Sawahlunto. PT. Bukit Asam (BA) Persero and its sub company, PT. Bukit Asam (Persero) Tbk. Ombilin Mining Unit (PTBA UPO) became the dominant private investor in the development of Sawahlunto as a tourism city. The outcomes from the visit of the Commission VII of The House of Representatives (DPR) summarized the CSR funds for the last five years funded by PT. BA increased specifically in 2018 on the UNESCO Cultural Heritage occasion (Commision VII Secretariat, 2019).

Table 3. PT. Bukit Asam's CSR Funds Realization for the West Sumatra

\begin{tabular}{|c|c|c|c|c|}
\hline 2015 & 2016 & 2017 & 2018 & 2019 \\
\hline $\begin{array}{l}\text { Rp. } \\
625.507 .300\end{array}$ & $\begin{array}{r}\text { Rp. } \\
526.900 .000\end{array}$ & $\begin{array}{r}\text { Rp. } \\
349.005 .648\end{array}$ & $\begin{array}{r}\text { Rp. } \\
11.771 .887 .570\end{array}$ & Rp. 4.245 .080 .870 \\
\hline
\end{tabular}

Source: Data taken from the Commision VII 2019 report

The CSR funds support from PT. BA towards tourism development was attained since the beginning of the master plan in 2003 until now. The CSR supports are infrastructures, human resource training and startup capital. Another CSR fund was also granted by the Ministry of State Owned Enterprises (BUMN).

In contrast to the majority of the tourism development in other cities, the allocation and realization of the CSR funds became the comparative advantage of Sawahlunto. In fact, CSR has been a media to achieve the 2020 vision and mission by accommodating the company's interest, local government policy and public welfare. 
Not only in the form of CSR funds, but the majority of museums in Sawahlunto are included in PT. BA inventory assets to achieve the vision of Sawahlunto in 2020. Six out of seven museums, which are PT. BA assets, managed by the local government, while the rest is managed directly by PT. BA. Moreover, PT. BA also launched an "Educational Hole" in one of the former mining sites to support the tourism and education of coals especially regarding the deep mines. PT. BA also renovated the Ombilin Hotel to enhance the accomodations in Sawahlunto that still needs to be much improved.

Private sector also takes part as the mobilizer of the tourist visits in Sawahlunto. The tour and travel agencies that offer the tour package to Sawahlunto have been one the main factors in increasing the number of tourists in Sawahlunto for the past ten years. The available domestic and foreign travel and tour packages as well as the tourism event publication in the promotional media have been confirmed as the significant marketing channels that attract the huge number of tourists with average long stay period in Sawahlunto.

Community

The approach to develop the vision and mission, starting the development after the economic slowdown due to the dependency on coal mining, provides a great learning to initiate a development with the long-term, accountable and systematic planning program that involves community in the decision making phase. The development orientation in Sawahlunto shifted to the people-centered or namely 'Community-based Development'. According to Loha (2018), the community based development will create a unique capacity and skill of its community. The collaboration will provide opportunities to the community to know their own strengths, perspectives and knowledge related to the other actors in the collaborations. In contrast to the previous conventional approach which was focused solely on the appointment of weaknesses as the point of view. The collective strength of the community is the ability to alleviate the local issues based on the community's current potential condition.

The community is the central goal of collaboration among stakeholders in Sawahlunto. The launch of the vision of a Cultural Tourism Mining City is indeed to improve the community welfare. The tremendous dependency on coal mining while the other types of resources emerge inevitably caused a high number of poverty in Sawahlunto of $17.18 \%$ in 2005 . Fortunately, the tourism development in the past two decades significantly lowered the poverty rate to $2.41 \%$ in 2009 (Asoka et al., 2003).

Community has been participating since the planning phase. The support from the community towards tourism is in accordance with the ecological reason of coal that is not environmentally sustainable. However, the challenges also emerged from the community itself, where there was hesitation in the concept of mining tourism with the mining activity itself where it is a 'rough work' in its nature. It seems to contradict each other. In addition, the community also worried about the newcomers.

The multiethnic community culture provides accessibility to socialize the vision and mission of Tourism City. As the socialization time goes by, each element of stakeholders have transformed the local community's paradigm. Through the partnership between local government and local tourism communities such as The Indonesian Tourist Guide Association (HPT), Association of The Indonesian Tours 
and Travel Agencies as well as the private sector, the community is well advocated and educated to be in the process of understanding how to shift into a tourism community. The community transformation took place when some informal workers shifted to becoming tour guides that offered tour services, accomodations, souvenirs and food service providers. To date, the community has expanded 48 out of 66 art centers and associations from the multiethnic mining community who come from Java, Batak, Bugis and other regions.

The youth group also sent their response in developing the tourism by establishing tourism-related groups to add the nature tour packages besides the mining tour package in the local community empowerment centers. The community becomes accelerators on how the mining tourism could be attained by involving them in both the idea implementation and operations to achieve the vision and mission. The different capacities owned by each actor develop dependency that could grow and strengthen commitment (Fairuza, 2017).

The cultural values have strategic roles in establishing the community participation in Sawahlunto. Culture becomes a social capital to encourage the human resources (SDM) or community to be proactive towards ideas in developing tourism.

Media

The role of media as promoter in supporting tourism in Sawahlunto does not specifically work for Business to Business (B2B) but also indirectly supports the information to be heard outside Sawahlunto even globally. Especially, the growth of both online and social media in the past decade attracted the tourists to have special interest in exploring the historical sites in Sawahlunto. Social media is one of the prominent channels in tourism promotion. Tourists do integrated multi channel communication to share their stories and give recommendations (Živković, Gajic, \& Brdar, 2014). Media publication in 2016 through the national TV has given huge access to the tourism publication in Sawahlunto.

Tabel 4. The Number of Domestic and Foreign Tourist in 3 Main Tourism Object 2016-2018

\begin{tabular}{ccc}
\hline Year & \multicolumn{2}{c}{ The Number of Tourists } \\
\cline { 2 - 3 } & $\begin{array}{c}\text { Foreign Tourists } \\
\text { (Person) }\end{array}$ & $\begin{array}{c}\text { Domestic Tourist } \\
\text { (Person) }\end{array}$ \\
\hline 2016 & 0 & 237.439 \\
\hline 2017 & 0 & 178.292 \\
\hline 2018 & 124 & 140.442 \\
\hline
\end{tabular}

Source: Department of Tourism and Sport Affairs of Sawahlunto, 2020 (edited)

Above table shows the increasing number of foreign tourist arrivals since 2018 after Sawahlunto was declared as one of the World Heritage to UNESCO in 2017. For instance, a notable person such as a national figure from West Sumatra 
visited Sawahlunto to know more about the tourism mining sites that he saw from the media all this time.

\section{DISCUSSION}

The stakeholders' involvement from the Pentahelix model provides different support power or capacity in attaining the vision and mission that complements and completes, well-coordinated to gain access to flexible collaboration with other parties. The local government's influence becomes a main driver to encourage other actors to be involved in establishing the tourism brand based on the characters of the community. Figure 1. The pentahelix stakeholder collaboration diagram in the
development of Sawahlunto City as a cultural mining tourism city

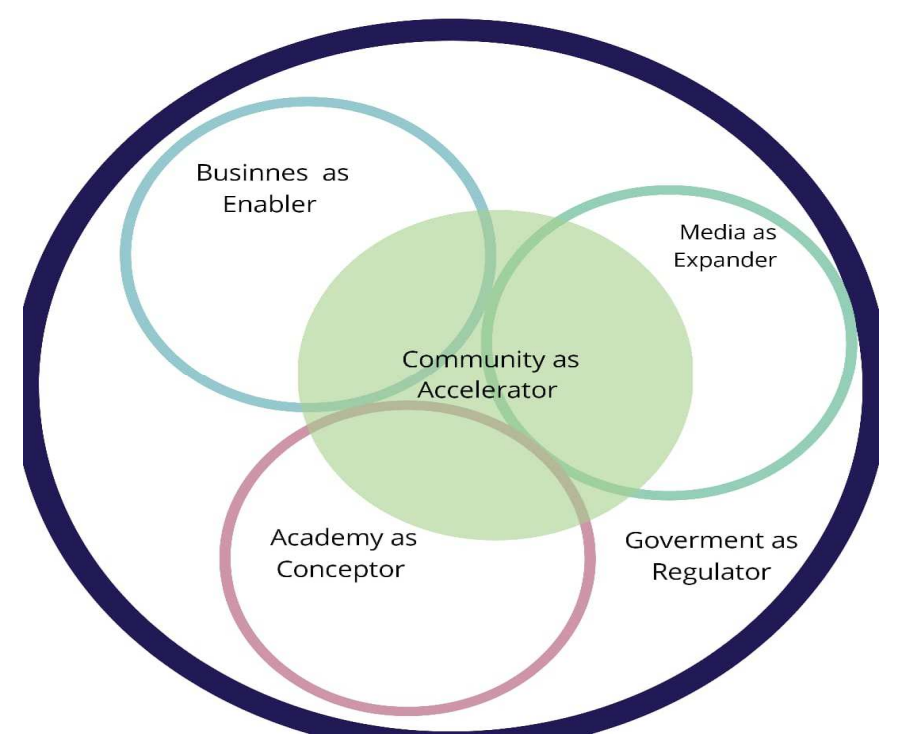

The role of stakeholders in Penta helix accordingly to the mission in developing the 2020 Mining Culture Tourism are divided into several functions:

1. The government, as a regulator, functions is to coordinate stakeholders by establish coonecting networks with the same vision which is development of mining cultural tourism city that is regulated as a regional policy. The government is also a facilitator who meditiates multi-stakeholder cooperation, so all the neccessity to achieve the vision and mission of the development can be acconplished by optimizing the role of stakeholders.

2. Academics as conceptor, functions is to convey developed concepts associated with theories and standard of development which scientifically accurate and carried impact learning that can be use as policy recommendations.

3. Business as an enabler, functions is to invest a number of social responsibility funds that help the Sawahlunto city meet the targets of its vision and mission. Business is also functions to mobilize tourist arrivals with promotional activities from various travel agents available.

4. Society as an accelerator. The Society is the central goal of stakeholder collaboration in Sawahlunto City. The declaration of the vision of a cultural mining tourism city cannot be separated from its aim to improve the welfare of 
the Society. Society involvement becomes a motor that can accelerate the achievement of the mission to be appointed for certification as a world heritage site.

5. Finally, the media as an expander, the media act as a liaison between stakeholders, provide support for improving the market and image of Sawahlunto City both at local and international.

\section{CONCLUSION}

The accomplishment of Sawahlunto to be known as one of the world's UNESCO Cultural Heritage is obtained by the commitment and amicable collaboration in participation of the government, academics, business, community and media. Each stakeholder runs a different role with the same goal to achieve the vision and mission of Sawahlunto as a Cultural Tourism City which leads to the revival of Sawahlunto's economy. Five stakeholders carry out their roles and functions optimally so that they become strong assets to develop Sawahlunto until it is ratified by UNESCO. There are only a few pentahelix collaborations created in Indonesia in supporting the development of a tourist destination, the pattern created in Sawahlunto can be a role model for stakeholders in developing tourist destinations.

\section{REFERENCES}

Ansell, C., \& Gash, A. (2008). Collaborative Governance in Theory and Practice. Journal of Public Administration Research and Theory, 18(4), 543-571. https://doi.org/https://doi.org/10.1093/jopart/mum032

Asoka, A., Samry, W., Zubir, Z., \& Zulqayyim. (2003). Sawahlunto Dulu Kini dan Esok Menjadi Kota wisata Tambang yang Berbudaya (No. 1). Padang.

Bank Indonesia. (2018). Wadah Harmoni Kebijakan Pusat dan Daerah Dorong Pariwisata Melalui Medsos. Jakarta: Departemen Komunikasi Bank Indonesia.

Creswell, J. W. (2014). Research Design: Pendekatan Kualitatif, Kuantitatif, dan Mixed (A. Fawaid, ed.). Yogyakarta: Pustaka Pelajar.

Elo, S., Kääriäinen, M., Kanste, O., Pölkki, T., Utriainen, K., \& Kyngäs, H. (2014). Qualitative Content Analysis. SAGE Open, 4(1), 1-10. https://doi.org/10.1177/2158244014522633

Fairuza, M. (2017). Kolaborasi antar stakeholder dalam pembangunan inklusif pada sektor pariwisata (studi kasus wisata Pulau Merah di Kabupaten Banyuwangi). Kebijakan Dan Manajemen Publik, 5(3), 1-13.

Komariah, A., \& Satori, D. (2011). Metode Penelitian Kualitatif. Bandung: Alfabeta Publisher.

Lindmark, A., Sturesson, E., \& Nilsson-Roos, M. (2009). Difficulties of 
collaboration for innovation - A study in the Öresund region. Lund University.

Loha, W. D. (2018). Community-led Development: Perspectives and Approaches of Four Member Organizations. SIT Graduate Institute.

Muhyi, H. A., Chan, A., Sukoco, I., \& Herawaty, T. (2017). The Penta Helix Collaboration Model in Developing Centers of Flagship Industry in Bandung City. Review of Integrative Business and Economics Research, 6(1), 412.

Pemerintah Kota Sawahlunto. Peraturan Daerah Kota Sawahlunto Nomor 6 Tahun 2003 tentang Penataan Kawasan Kota Lama. , (2003). Indonesia.

Pemerintah Kota Sawahlunto. Peraturan Daerah Kota Sawahlunto Nomor 6 Tahun 2007 tentang Pengelolaan Benda Cagar Budaya. , (2007). Indonesia.

Pemerintah Kota Sawahlunto. Peraturan Daerah Kota Sawahlunto Nomor 2 Tahun 2010 tentang Penataan Kawasan Kota Lama. , (2010). Indonesia.

Presiden Republik Indonesia. Undang-Undang Republik Indonesia nomor 22 Tahun 1999 tentang Pemerintahan Daerah. , (1999). Indonesia.

Soemaryani, I. (2016). Pentahelix Model to Increase Tourist Visit to Bandung and its Surrounding Areas through Human Resource Development. Academy of Strategic Management Journal, 15(3), 249-259.

Sugiyono. (2010). Metode Penelitian Kuantitatif, Kualitatif, dan R\&D. Bandung: Alfabeta.

Suprayoga, G. B. (2008). Identitas Kota Sawahlunto Paska Kejayaan Pertambangan Batu Bara. Journal of Regional and City Planning, 19(2), 121.

Syafrini, D., \& Fernandes, R. (2017). Dampak Pergeseran Kebijakan Kota Tambang Menjadi Kota Wisata Tambang Berbudaya pada Kehidupan Sosial Masyarakat di Kota Sawahlunto. Journal of Sociology Research and Education, 4, 74-81.

Yin, R. K. (2015). Studi Kasus Desain \& Metode. Jakarta: Rajawali Pers. https://doi.org/https://doi.org/10.24036/scs.v4i2.23

Živković, R., Gajic, J., \& Brdar, I. (2014). The Impact of Social Media on Tourism. Prva Međunarodna Konferencija Sinteza. Belgrade. https://doi.org/10.15308/sinteza-2014-758-761

Zubir, Z., \& Zulqayyim. (2014). Rontoknya Dominasi Negara Tambang Batu Bara Ombilin Sawahlunto. Jurnal Ilmus Sosial Mamangan, 1(II), 15-26. 